\title{
KEKOSONGAN HUKUM JASA USAHA KEPELABUHAN AKIBAT PEMBATASAN OBYEK RETRIBUSI DAERAH
}

\author{
Sukardi dan Dri Utari Christina Rahmawati \\ sukardi@fh.unair.ac.id; driutari03_unair@yahoo.com \\ Fakultas Hukum Universitas Airlangga
}

\begin{abstract}
Local autonomy based on the Act No. 22 Year 1999 about Local Autonomy (amended by the Act No. 32 Year 2004 about Local Governance) has delivered broad autonomy to local governance to add its local revenue through cllection, local tax and local retribution. The impementation of local autonomy should be in the line with the unitary state of Indnesia as attached in the Constitution 1945 and other supporting rules in legislation. The formation of Local Procedures by Local Governance should not only partially benefit local governance but also they need pay attention to their functions in public services. Retribution withdrawal by Gresik Regency towards 8 ports for own interests should be based on the hierarchy of the regulations. It means that in the art of the Local Rules should not be contrary to the higher rules.
\end{abstract}

Keywords: local autonomy, retriution, local rules, public service.

\begin{abstract}
Abstrak
Otonomi daerah berdasarkan Undang-Undang Nomor 22 tahun 1999 tentang Pemerintahan Daerah yang telah diamandemen dengan Undang-Undang Nomor 32 tahun 2004 tentang Pemerintahan Daerah telah memberikan kewenangan yang luas kepada Pemerintahan Daerah untuk dapat menambah Pendapatan Asli Daerah-nya melalui pungutan antara lain pajak daerah dan retribusi daerah. Pelaksanaan otonomi daerah hendaknya tetap dalam koridor Negara Kesatuan Republik Indonesia sebagaimana terlampir dalam UndangUndang Dasar Negara Kesatuan Republik Indonesia 1945 dan peraturan penunjang lainnya di tataran legislasi. Pembentukan Peraturan Daerah oleh Pemerintahan Daerah tentu saja tidak boleh hanya menguntungkan mereka secara sepihak, tetapi tetap memperhatikan fungsi mereka dalam rangka melaksanakan pelayanan publik. Penarikan Retribusi oleh Pemerintah Kabupaten Gresik terhadap 8 (delapan) Dermaga Untuk Kepentingan Sendiri berdasarkan Peraturan Daerah seharusnya disesuaikan dengan hirarki peraturan perundang-undangan yang berlaku. Artinya pasal-pasal dalam Peraturan Daerah tersebut tidak boleh bertentangan dengan Peraturan perundang-undangan di atasnya.
\end{abstract}

Kata kunci: otonomi daerah, retribusi, peraturan daerah, pelayanan publik. 


\section{Pendahuluan}

Pasal 18 ayat (2) Undang-Undang Dasar Negara Republik Indonesia 1945 (UUD NRI 1945) telah memberikan kewenangan konstitusional kepada Pemerintahahan Daerah Provinsi, Daerah Kabupaten, dan Kota untuk dapat mengatur dan mengurus sendiri urusan pemerintahannya sesuai dengan asas otonomi dan tugas pembantuan. Berdasarkan Pasal 1 angka 5 Undang-Undang No. 32 Tahun 2004 tentang Pemerintahan Daerah (UU No. 32/2004), maka otonomi daerah adalah hak, wewenang, dan kewajiban daerah otonom untuk mengatur dan mengurus sendiri urusan pemerintahan dan kepentingan masyarakat sesuai dengan peraturan perundang-undangan.Mengacu pada Pasal 1 angka 5 tersebut, maka Pemerintah Daerah Kabupaten Gresik (Pemkab. Gresik) yang melakukan pemerintahan otonomi daerah berwenang membuat peraturan sendiri dalam rangka menjalankan otonomi daerahnya, termasuk diantaranya membuat dasar hukum untuk mendapatkan Pendapatan Asli Daerah (PAD), sebagai usaha untuk dapat membiayai segala kebutuhan daerahnya sendiri.

Pengelolaan Dermaga Untuk Kepentingan Sendiri (DUKS) di Kabupaten Gresik sepenuhnya dilakukan oleh PT. Pelindo III (Persero) sebagai Badan Usaha Milik Negara (BUMN). DUKS tersebut adalah: (1) DUKS PT. Maspion; (2) DUKS PT. Smelting; (3) DUKS PT. Petrokimia Gresik; (4) DUKS PT. PertaminaAsphalt; (5) DUKS PT. PLN PJB II Gresik; (6) DUKS PT. Semen Gresik;(7) DUKS PT. Indonesia Marina Shipyard; dan (8) DUKS PT. Nusantara Plywood.

Pasca otonomi daerah, Pemkab. Gresik merasa lebih berwenangmengelola DUKS tersebut untuk meningkatkan PAD. Pemkab. Gresik serta menarik retribusi dari setiap DUKS tersebut berdasarkan pada UU 32/2004; Peraturan Daerah Nomor 3 tahun 2001 tentang Penataan Ruang Pantai Pesisir dan Pelabuhan tahun 2000 sampai 2010 (Perda No. 3/2001);Peraturan Daerah Kabupaten Gresik No. 19 tahun 2001 tentang Kepelabuhan di Kabupaten Gresik (Perda No.19/2001); dan Peraturan Daerah Kabupaten Gresik No. 9 tahun 2002 tentang Retribusi Jasa Kepelabuhan di Kabupaten Gresik (Perda No.9/2002).

Permasalahan timbul dengan diundangkannya Undang-Undang No. 17 tahun 2008 tentang Pelayaran (UU No. 17/2008) dan Undang-Undang No. 28 tahun 2009 tentang Pajak Daerah dan Retribusi Daerah (UU No. 28/2009). Secara khusus UU 17/2008 menyebutkan bahwa penarikan retribusi dilakukan oleh Otoritas Pelabuhan (OP) sedangkan berdasarkan Perda No. 19/2001 penarikan dilakukan oleh Pemerintah Kabupaten Gresik sendiri terhadap Badan Usaha Pelabuhan sebagai upaya mendapatkan tambahan PAD. Sebagai dasar pelaksanaan teknis penarikan tarif sesuai Pasal 36 Perda No.19/2001, maka tarif pelayanan kepelabuhan ditetapkan dengan Keputusan Bupati Gresik No. 63 tahun 2002 tentang Tarif Jasa Pelayaran Kepelabuhan Oleh Penyelenggara Pelabuhan di Kabupaten Gresik. Berdasar UU No. 28/2009 Pasal 135 ayat (2), maka ada pelabuhan yang dikecualikan dari obyek retribusi yaitu pelayanan jasa kepelabuhan yang disediakan, dimiliki dan/atau dikelola oleh 
Pemerintah, BUMN, BUMD, dan pihak swasta. Artikel ini membahas kewenangan Pemkab Gresik dalam menarik retribusi di setiap DUKS yang ada di wilayah Kabupaten Gresik untuk penambahan PAD-nya dan pihak-pihak yang akan diuntungkan dan/atau dirugikan bila penarikan retribusi tetap dilakukan oleh Pemkab. Gresik atau diganti dengan bentuk penarikan pajak.

Artikel ini adalah hasil dari penelitian yuridis normatif yang menggunakan beberapa metode pendekatan yaitu statute approach, pendekatan ini dilakukan dengan menelaah semua Undang-Undang dan regulasi yang bersangkut paut dengan dengan isu hukum yang sedang ditangani. ${ }^{1}$ Pendekatan berikutnya yang dilakukan adalah conceptual approach dimana pendekatan ini beranjak dari pandangan-pandangan dan doktrin-doktrin yang berkembang di dalam ilmu hukum. ${ }^{2}$

\section{Kewenangan PT. Pelabuhan Indonesia III (Persero) di Setiap Dermaga Untuk Kepentingan Sendiri (DUKS) Sebelum Pelaksanaan Otonomi Daerah}

Sebelum diberlakukannya otonomi daerah di Kabupaten Gresik, mekanisme penarikan retribusi terhadap jasa usaha pelayanan kepelabuhan terhadap 8 DUKS dilakukan oleh PT. Pelabuhan Indonesia III (Persero), BUMN yang bergerak di bidang perhubungan. Undang-Undang Nomor 19 tahun 2003 tentang Badan Usaha Milik Negara (UU No. 19/2003) menyatakan bahwa BUMN adalah badan usaha yang seluruh atau sebagian besar modalnya dimiliki oleh negara melalui penyertaan secara langsung yang berasal dari kekayaan negara yang dipisahkan, dan dapat berbentuk perusahaan perseroan, perusahaan umum, dan perusahaan jawatan.

Sejarah pengelolaan pelabuhan di Indonesia secara umum, dimulai sejak kemerderdekaan RI tahun 1945. Meskipun demikian mulai tahun 80-an Pemerintah menunjuk BUMN sebagai pengelola pelabuhan dengan membentuk Perusahaan Umum (Perum) pelabuhan I, II, III, dan IV. Perum Pelabuhan kemudian berbentuk Perseroan Terbatas pada tahun 1992 dan berubah nama menjadi PT. Pelabuhan Indonesia (Persero) I, II, III dan Pelindo IV. ${ }^{3}$

Guna memperlancar usaha pelabuhan Gresik, maka ditetapkan daerah lingkungan pelabuhan. Dalam hal ini terdapat beberapa ketetapan yang diawali dan ditetapkan saat pemerintah Belanda sampai dengan pemerintahan Republik Indonesia dengan surat-surat keputusan, diantaranya sebagai berikut: 1) Surat Keputusan Gubernur Jenderal Hindia Belanda, tanggal 6 Maret 1931 Nomor 18 (S. 1931-102) ; 2) Surat Keputusan Kepala Daerah Kabupaten Surabaya (sekarang Kabupaten Gresik) Nomor: U/31/PU/AA, tanggal 13 Juli 1964; 3) Surat Keputusan DPR-DGR Daerah Tingkat II Surabaya Nomor: U/32/PU.DPR-

\footnotetext{
Peter Mahmud Marzuki, Penelitian Hukum, Jakarta: Kencana, 2009, h. 93.

Ibid, h. 95.

3 Umi Elan, "Pengaruh Keputusan Kerja Terhadap Kinerja Karyawan PT. Pelindo III Cabang Gresik", Cahaya Kampus, Jurnal Ilmiah Universitas Gresik, Vol. 14 No. 1, Mei-Oktober 2013, h. 24-25.
} 
DGR, tahun 1964; 4) Surat Keputusan Bersama Menteri Perhubungan dengan Menteri Dalam Negeri Nomor 169 tahun 1996, tanggal 2 Oktober 1996. ${ }^{4}$

\section{Kewenangan Pemerintah Daerah Kabupaten Gresik Menarik Retribusi di Setiap Dermaga Untuk Kepentingan Sendiri (DUKS) Setelah Pelasanaan Otonomi Daerah}

John H. Garvey dan T. Alexander Aleinikooff berpendapat bahwa terdapat dua bentuk pembagian kekuasaan: The former is sometimes said to address the "vertical" division of authority between national and state governments, the latter a "horizontal" division among the executive, legislature, and judiary. ${ }^{5}$ Arthur Maass juga berpendapat bahwa pembagian kekuasaan secara horisontal disebut sebagai capital devision of power, sedangkan pembagian kekuasaan secara vertikal disebut sebagai areal division of power. Dalam rangka capital devision of power, fungsi legislatif, eksekutif, dan yudikatif masing-masing diberikan kepada suatu badan. Dalam rangka areal devision of power, fungsi-fungsi tertentu misalnya moneter dan hubungan luar negeri diberikan kepada pemerintah pusat, sedangkan fungsifungsi lainnya diberikan kepada negara bagian atau pemerintah daerah. ${ }^{6}$

Muhammad Fauzan memberikan indikator pada suatu negara untuk dapat diklasifikasikan sebagai sebuah negara kesatuan, yaitu: 1) kedaulatan tertinggi ada pada pemerintahan nasional; (2) penyerahan suatu kekuasaan atau wewenang kepada satuan pemerintah lokal hanya dapat dilaksanakan atas kuasa undang-undang yang dibuat oleh badan legislatif nasional; dan (3) tidak ada satuan pemerintah yang lebih rendah yang mempunyai staat. ${ }^{7}$ Indikator ke-satu terlihat dalam Pasal 1 ayat (2) UUD NRI 1945 dan Pasal 4 ayat (1) UUD NRI 1945. Indikator ke-dua terpenuhi dengan diundangkannya UU No. 32/2004 dan indikator ke-tiga, dipenuhi oleh Pasal 1 ayat (1) UUD NRI 1945 dan Pasal 18 ayat (1) UUD NRI 1945.

Pasal 2 ayat (2) UU No.32/2004 menyatakan bahwa Pemerintah Daerah mengatur dan mengurus sendiri urusan pemerintahan menurut asas otonomi dan tugas pembantuan. Syariff Saleh mengatakan otonomi itu sebagai hak mengatur dan memerintah daerah sendiri. Atas inisiatif dan kemauan sendiri, dimana hak tersebut diperoleh dari Pemerintah Pusat. ${ }^{8}$ Wayong mengemukakan bahwa otonomi daerah itu adalah kebebasan untuk memelihara dan memajukan kepentingan khusus daerah, dengan keuangan sendiri, menentukan hukum sendiri dan berpemerintahan sendiri. ${ }^{9}$ Sugeng Istanto menyatakan bahwa otonomi diartikan sebagai hak atau wewenang untuk mengatur dan mengurus rumah tangga daerah. ${ }^{10}$

$4 \quad$ Ibid, h. 25.

5 Edie Toet Hendratno, Negara Kesatuan, Desentralisasi, dan Federalisme, Yogyakarta: Graha Ilmu, 2009, h.120.

6 Ibid, h. 121.

7 Muhammad Fauzan, Hukum Pemerintahan Daerah - Kajian Tentang Hubungan Keuangan antara Pusat dan Daerah, Yogyakarta:UII Press, 2006, h. 37.

8 Syarif Saleh, Otonomi dan Daerah Otonom, Endang, Jakarta, 1953, h. 31.

9 J. Wayong, Asas dan Tujuan Pemerintahan Daerah, Jakarta: Jambatan, 1975, h. 5.

10 F. Sugeng Istanto, Beberapa Segi Hubungan Pemerintah Pusat dan Daerah dalam Negara Kesatuan 
Berangkat dari hal tersebut maka inti pelaksanaan otonomi daerah adalah terdapatnya keleluasaan pemerintah daerah (discretionary power) untuk menyelenggarakan pemerintahan sendiri atas dasar prakarsa, kreativitas dan peran serta aktif masyarakat dalam rangka mengembangkan dan memajukan daerahnya. ${ }^{11}$ Disini masyarakat tidak saja dapat menentukan nasibnya sendiri melalui pemberdayaan masyarakat, melainkan yang utama adalah berupaya untuk memperbaiki nasibnya sendiri. ${ }^{12}$ Sebagai upaya melaksanakan asas otonomi daerah, maka Pemkab Gresik perlu meningkatkan kesejahteraan dari masyarakatnya, salah satu caranya dengan meningkatkan sumber Pendapatan Asli Daerah (PAD).

Mahmudi berpendapat bahwa salah satu sumber pendapatan daerah pada dasarnya dapat diperoleh dari sumber pendapatan yang saat ini ada dan sudah ditetapkan dengan peraturan perundang-undangan. ${ }^{13}$ Sesuai dengan UU No. 32/2004 (sebelumnya UU Nomor 22 tahun 1999) dan Undang-Undang Nomor 33 tahun 2004 tentang Perimbangan Keuangan Antara Pemerintah Pusat dan Daerah (UU No. 33/2004) (sebelumnya UU Nomor 25 tahun 1999) telah menetapkan sumber PAD sebagai berikut: 1) Pajak daerah; 2) Retribusi daerah; 3) Hasil pengelolaan kekayaan daerah yang dipisahkan (sebelumnya hasil perusahaan milik daerah dan hasil pengelolaan kekayaan daerah lainnya yang dipisahkan); 4) Lain-lain Pendapatan Asli Daerah yang sah.

Terkait dengan kondisi Kabupaten Gresik, maka potensi untuk mendapatkan PAD yang maksimal dan menguntungkan daerah adalah dengan melalui pengelolaan kepelabuhan atas 8 DUKS yang ada di wilayah Kabupaten Gresik. Membiayai diri sendiri atau pendapatan sendiri menunjukkan bahwa Daerah (harus) mempunyai sumber-sumber pendapatan sendiri. Salah satu sumber pendapatan asli adalah pungutan yang diperoleh dari pajak atau retribusi. Kewenangan untuk mengenakan pungutan, bukan sekadar sebagai sumber pendapatan, tetapi sekaligus melambangkan kebebasan untuk menentukan sendiri cara-cara mengatur dan mengurus urusan rumah tangga daerah yang bersangkutan. ${ }^{14}$

Berdasarkan konsep pemberlakuan otonomi daerah yang diharapkan dapat memberikan masukan yang maksimal kepada Pemkab Gresik yang juga diperkuat dengan pemberlakuan UU No.22/1999, maka Pemkab. Gresik mengesahkan beberapa peraturan perundang-undangan untuk memperkuat keabsahan pengelolaan DUKS yaitu Perda No.3/ 2001, Perda No.19/2001, dan PerdaNo. 9/ 2002. Pemberlakuan UU No. 22/1999 (selanjutnya dirubah dengan UU 32/2004) adalah titik awal pemberlakuan dasar hukum bagi Pemkab. Gresik untuk mengambil alih pengelolaan pelabuhan Gresik. Pasal 18 UU No. 32/2004 memberikan kewenangan pada daerah untuk mengelola sumber daya di wilayah lautnya. Kewenangan itu meliputi eksplorasi, eksploitasi, konservasi, pengelolaan kekayaan

Indonesia, Yogyakarta: Karyaputera, 1971, h. 24.

11 H.A.W. Widjaja, Percontohan Otonomi Daerah di Indonesia, Jakarta: Rineka Cipta, 1998, h. 36.

12 Edie Toet H. Op.Cit., h. 64.

13 Mahmudi, Manajemen Keuangan Daerah, Jakarta: Erlangga, 2010, h. 16.

14 Muhammad Fauzan, Op.cit., h. 227. 
laut, pengaturan administrasi, pengaturan tata ruang, termasuk penegakan hukum terhadap peraturan daerah wilayah kabupaten/kota sejauh 1/3 dari wilayah laut provinsi atau 4 mil (dari garis pantai) ke laut lepas.

Menurut Ach. Effendi MT (Kepala Seksi Kepelabuhan Gresik) dan Dharmi Suwanto (Kasubdin Perhubungan Laut, Sungai, dan Danau) Pasal 18 ayat 3b UU No. 32/2004 semakin memperjelas bahwa pengaturan administrasi adalah perizinan, kelaikan dan keselamatan, sehingga kewenangan wilayah laut pemerintah kabupaten/kota termasuk dalam hal eksplorasi (pencarian sumber daya laut), eksploitasi (Pemanfaatan, pengambilan sumber daya alam di laut yang terkandung di permukaan, serta di dalam laut). Pengaturan administratif dan perizinan atas wilayah laut 4 mil (dari garis pantai) termasuk pengaturan tata ruang wilayah laut. ${ }^{15}$ Pasal 18 ayat (5) UUD NRI 1945 dan UU No.32/2004 juga memperkuat dasar penarikan retribusi oleh Pemkab. Gresik untuk mendapatkan PAD sebesar-besarnya.

Rohmat Sumitro mendefinisikan retribusi daerah sebagai pembayaran kepada negara yang dilakukan kepada mereka yang menggunakan jasa-jasa negara, artinya retribusi daerah sebagai pembayaran atas jasa atau karena mendapat pekerjaan usaha atau milik daerah bagi yang berkepentingan, atau jasa yang diberikan oleh daerah baik secara langsung maupun tidak langsung. Jadi retribusi sangat berhubungan erat dengan jasa layanan yang diberikan pemerintah daerah kepada yang membutuhkan. ${ }^{16}$ Menurut Davey, pembayaran retribusi harus memenuhi dua syarat, yaitu: 1) dasar untuk mengenakan retribusi biasanya harus didasarkan pada total cost dari pada pelayanan-pelayanan yang disediakan; dan 2) dalam beberapa hal, retribusi biasanya harus didasarkan pada kesinambungan harga jasa suatu pelayanan, yaitu atas dasar mencari keuntungan. Menurut Josep Riwu Kaho, ada beberapa ciri retribusi, yaitu: 1) retribusi dipungut oleh negara; 2) dalam pungutan terdapat paksaan secara ekonomis; 3) adanya kontra prestasi yang secara langsung dapat ditunjuk; 4) retribusi dikenakan kepada setiap orang/badan yang menggunakan/mengenyam jasa-jasa yang disediakan oleh negara. ${ }^{17}$

Ketika Pemkab. Gresik menarik retribusi daerah kepada setiap DUKS yang berada di dalam wilayahnya, maka Pemkab. Gresik telah menyediakan fasilitas wilayah kepada setiap DUKS tersebut. Secara umum, keunggulan utama sektor retribusi ialah karena didasarkan pada kontraprestasi, dimana tidak ditentukan secara limitatif, seperti halnya sektor pajak. Pembatasan utama sektor retribusi ialah terletak pada ada atau tidaknya jasa yang disediakan pemda. Oleh sebab itu, sebenarnya pemda dapat saja mengusahakan retribusi selama ia dapat menyediakan jasa untuk itu. ${ }^{18}$ Dasar hukum penarikan retribusi pada DUKS di wilayah Kabupaten Gresik adalah Undang-Undang Nomor 34 tahun 2000 tentang Perubahan Atas Undang-Undang Nomor 18 tahun 1997 tentang Pajak dan Retribusi Daerah (UU No.

\footnotetext{
15 Yayasan Inovasi Pemerintahan Daerah, http://www.yipd.or.id/main/readnews/552, diunduh 15 Oktober 2013.

16 Adrian Sutedi, Hukum Pajak dan Retribusi Daerah, Bogor: Ghalia Indonesia,2008, h. 74.

17 Ibid, h. 75.

18 Ibid,h. 85.
} 
34/2000). Perubahan tersebut seriring dengan perubahan tentang UU No. 22/1999 dan Undang-Undang Nomor 25 tahun 1999 tentag Perimbangan Keuangan antara Pemerintah Pusat dan Daerah (UU No. 25/1999). Pemkab. Gresik menindak lanjuti peraturan tersebut dengan membentuk Perda No. 19/2001, bahwa Pemkab. Gresik dapat menarik retribusi terhadap Badan Usaha Pelabuhan (BUP). Pasal 36 Perda No. 19/2001 menyatakan bahwa tarif retribusi terhadap pelayanan kepelabuhan akan ditetapkan dengan Keputusan Bupati, yang dalam hal ini diatur dengan Keputusan Bupati Gresik Nomor 63 tahun 2002.

Anggaran Pendapatan dan Belanja Daerah bersumber dari Pendapatan Asli Daerah dan penerimaan berupa Dana Perimbangan yang bersumber dari Anggaran Pendapatan dan Belanja Negara. Pendapatan Asli daerah, yang antara lain berupa Pajak Daerah dan retribusi Daerah, diharapkan menjadi salah satu sumber pembiayaan penyelenggaraan pemerintahan dan pembangunan daerah, untuk meningkatkan dan memeratakan kesejahteraan masyarakat. Dengan demikian, daerah mampu melakukan otonomi, yaitu mampu mengatur dan mengurus rumah tangganya sendiri. ${ }^{19}$

Seperti telah diungkapkan di atas, prinsip yang melekat dalam UU No. 22/1999 dan UU No.25/1999 adalah memberikan wewenang daerah untuk mengatur dan memberdayakan daerahnya sesuai dengan kemampuan yang dimiliki. Daerah yang selama puluhan tahun serba diatur oleh pemerintah (pusat), kini memperoleh keleluasaan untuk mengembangkan insiatif. Era serba menunggu petunjuk pelasanaan dan petunjuk teknis segera digantikan oleh era pro-aktif penuh kemandirian. Kendati begitu bukan berarti bahwa daerah bisa semaunya sendiri atau boleh mengembangkan tindakan yang autharki. Daerah tetap harus berjalan sesuai dengan koridor pemerintahan yang berlaku baik di tingkat nasional maupun di tingkat provinsi, terutama perlu disadaribahwa kebijakan otonomi daerah bukan akan melembagakan keinginan membentuk 'negara dalam negara', tetapi mengambil sebagian wewenang yang selama ini dikuasai oleh pemerintah pusat. ${ }^{20}$

\section{Konsep dan Mekanisme Pelayanan Publik}

Motif Pemkab. Gresik untuk mengelola DUKS yang berada di wilayahnya merupakan salah satu perwujudan dari pelayanan publik. Menurut Agung Kurniawan, pelayanan publik diartikan pemberian layanan (melayani) keperluan orang atau masyarakat yang mempunyai kepentingan pada organisasi itu sesuai dengan aturan pokok dan tata cara yang ditetapkan. ${ }^{21}$ Menurut AG. Subarno, pelayanan publik merupakam produk birokrasi publik yang diterima oleh warga pengguna maupun masyarakat secara luas. Karena itu, pelayanan publik dapat didefinisikan sebagai serangkaian aktivitas yang dilakukan oleh birokrasi publik untuk

19 Adrian Sutedi, Implikasi Hukum Atas Sumber Pembiayaan Daerah Dalam Kerangka Otonomi Daerah, Jakarta: Sinar Grafika, 2009, h. 150-151.

20 Sunyoto Usman, Op.cit., h. 120.

21 Agung Kurniawan, Transformasi Pelayanan Publik, Yogyakarta: Pembaruan, 2005, h. 4. 
memenuhi kebutuhan warga pengguna. ${ }^{22}$ Undang-Undang Nomor 25 tahun 2009 tentang Pelayanan Publik (UU No.25/2009), Pasal 1 angka (1) menyatakan "Pelayanan publik adalah kegiatan atau rangkaian kegiatan dalam rangka pemenuhan kebutuhan pelayanan sesuai dengan peraturan perundang-undangan bagi setiap warga negara dan penduduk atas barang, jasa, dan /atau pelayanan administratif yang disediakan oleh penyelenggara pelayanan publik."

Pengelolaan DUKS oleh Pemkab. Gresik sangat berkaitan erat dengan masalah perekonomian, terutama sumber PAD. Dalam perspektif ekonomi, pelayanan publik adalah semua bentuk pengadaan barang dan jasa oleh pemerintah (sektor publik yang diperlukan oleh warga negara sebagai konsumen). ${ }^{23}$ Pengelolaan DUKS oleh Pemkab. Gresikdapat dikategorikan sebagai pelayan publik dalam hal jasa, sesuatu yang susah untuk dibuat indikator kualitasnya dandisediakan oleh pihak pemerintah berdasarkan UU No. 22/1999 dan tiga Perda yang dibuat untuk implementasinya yaitu Perda No. 3/2001, Perda No. 19/2001, dan Perda No. 9/2002 serta Keputusan Bupati Gresik No. 63/2002.

Meskipun secara teori sukar untuk mengukur kinerja yang dilakukan oleh Pemkab. Gresik jika dibandingkan dengan pengelola DUKS sebelumnya, tetapi sebagai penyelenggara pelayanan publik, Pemkab. Gresik harus tetap memperhatikan tujuan utama pelayanan publik. Menurut AG. Subarsono, tujuan pelayanan publik tetap harus memenuhi kebutuhan warga pengguna agar dapat memperoleh pelayanan yang diinginkan dan memuaskan. Karena itu, penyedia layanan harus mampu mengidentifikasi kebutuhan dan keinginan warga penggunanya, kemudian memberikan pelayanan sesuai dengan keinginan dan kebutuhan warga tersebut. ${ }^{24}$ Alangkah baiknya sebagai pengganti PT. Pelindo III (Persero), Pemkab. Gresik harus tetap memberikan pelayanan yang terbaik, meskipun bertujuan untuk memperoleh pendapatan yang sebesar-besarnya bagi PAD Kabupaten Gresik. Perhatian yang penuh terhadap kebutuhan pelanggan atau pengguna yang di dalam sistem perbankan disebut Know Your Customers (KYC). Terkait dengan startegi KYC, maka pelayanan publik digunakan untuk mengenali kebutuhan, kepentingan dan aspirasi pengguna layanan agar penyelenggaraan layanan publik bersifat responsif. ${ }^{25}$

Asas-asas penyelenggaraan publik juga dinyatakan dalam Pasal 4 UU No. 25/2009 yaitu kepentingan umum, kepastian hukum, kesamaan hak, keseimbangan hak dan kewajiban, keprofesionalan, partisipatif, tidak diskriminatif, keterbukaan, akuntabilitas, rentan, ketepatan waktu, kecepatan, kemudahan, dan keterjangkauan.Hukum Administrasi Negara mengenal prinsip-prinsip atau asas-asas umum penyelenggaraan administrasi yang baik (general principle of good administrationatau AAUPB). Menurut Marbun, bagi

22 AG. Subarsono,Pelayanan Publik yang Efisien, Responsif, dan Non-Partisan - Mewujudkan Good Governance Melalui Pelayanan Publik, Yogyakarta: Gadjah Mada University Press, 2008, h. 136.

23 Sirajudin, Didik S., Winardi, Hukum Pelayanan Publik Berbasi Partisipasi \& Keterbukaan Informasi, Malang: Setara Press, 2011, h. 11.

${ }^{24}$ AG. Subarsono, Op.Cit., h. 149.

25 Ibid, h. 142. 
administrasi negara, AAUPB bermanfaat sebagai pedoman dalam melakukan penafsiran dan penerapan terhadap ketentuan peraturan perundang-undangan yang masih kabur/sumir atau kurang jelas, sementara bagi rakyat pencari keadilan dapat digunakan sebagai dasar mengajukan gugatan terhadap keputusan tata usaha negara yang merugikan dan tentu saja bagi hakim sekaligus menjadi alat menguji dan membatalkan keputusan yang dikeluarkan oleh badan atau pejabat tata usaha negara. ${ }^{26}$

Kinerja aparat Pemkab. Gresik yang susah untuk diukur setidaknya dapat digolongkan sebagai tindakan maladministrasi sebagaimana dinyatakan Pasal 1 angka 3 Undang-Undang Nomor 37 tahun 2008 tentang Ombudsman Republik Indonesia (UU No.37/2008),jika aparat melakukan perbuatan melawan hukum, melampaui wewenang, menggunakan wewenang untuk tujuan lain dari yang menjadi tujuan wewenang tersebut, termasuk kelalaian atau pengabaian kewajiban hukum dalam penyelenggaraan pelayanan publik yang dilakukan oleh penyelenggara negara dan pemerintahan yang menimbulkan materiil dan/atau immateriil bagi masyarakat dan orang perseorangan. Menurut Sunaryati, bentuk maladministrasi dapat dikategorikan menjadi enam kelompok yaitu: 1) terkait dengan ketepatan waktu dalam proses pemberian pelayanan umum; 2) adanya keberpihakan yang menimbulkan diskriminasi; 3) bentuk pelanggaran terhadap hukum dan peraturan perundang-undangan; 4) berkaitan dengan kewenangan atau kompetensi yang berdampak pada kualitas pelayanan umum pejabat publik kepada masyarakat; 5) mencerminkan sikap arogansi seorang pejabat publik dalam proses pemberian pelayanan umum; 6) adanya tindakan korupsi secara aktif. ${ }^{27}$

\section{Kewenangan Pemerintah Kabupaten Gresik Akibat Berlakunya Undang-Undang No- mor 17 Tahun 2008 Tentang Pelayaran dan Undang-Undang Nomor 28 Tahun 2009 Tentang Pajak Daerah dan Retribusi Daerah}

Kewenangan Pemkab. Gresik untuk mengelola 8 DUKS di wilayahnya menggantikan PT. Pelindo III (Persero) sebenarnya tidak akan menimbulkan konflik dalam pelaksanaannya jika tidak ada pembaharuan peraturan yang terkait dengan Pelayaran, Pajak dan Retribusi. Pengelolaan DUKS tersebut untuk mendapatkan PAD sebesar-besarnya bagi Pemkab. Gresik adalah hal yang wajar dan diperbolehkan secara hukum, apalagi telah dijamin baik oleh UUD NRI 1945, UU No. 22/1999 (UU No. 32/2004) dan beberapa Peraturan Daerah.Usaha yang telah dilakukan oleh Pemkab. Gresik dalam rangka untuk menarik hasil PAD melalui penarikan retribusi pada DUKS di wilayahnya selanjutnya memperoleh kendala dengan diundangkannya Undang-Undang Nomor 17 tahun 2008 tentang Pelayaran(UU No. 17/2008) dan Undang-Undang Nomor 28 tahun 2009 tentang Pajak Daerah dan Retribusi (UU No. 28/2009). Huruf b Penjelasan Umum UU No. 17/2008 menyatakan bahwa terkait dengan pengaturan kepelabuhan perlu dilakukan penghapusan monopoli dalam penyelenggaraan

\footnotetext{
26 Sirajuddin, Op.Cit., h. 36.

27 Ibid, h.187-191.
} 
pelabuhan, pemisahan antara fungsi regulator dan operator serta memberikan peran serta pemerintah daerah dan swasta secara proporsional di dalam penyelenggaraan kepelabuhanan. Terhadap BUMN yang selama ini telah menyelenggarakan kegiatan pengusahaan pelabuhan tetap dapat menyelenggarakan kegiatan yang sama dengan mendapatkan pelimpahan kewenangan Pemerintah, dalam upaya meningkatkan peran BUMN guna mendukung pertumbuhan ekonomi.

Beberapa pasal dalam UU No. 17/2008 menegaskan bahwa penyelenggara pelabuhan adalah Otoritas Pelabuhan (OP) yang dibentuk di pelabuhan komersial dan Unit Penyelenggara Pelabuhan (UPP) yang dibentuk di pelabuhan yang belum komersial (Pasal 81). Pasal 81 ayat (4) menyatakan bahwa UPP dapat merupakan UPP Pemerintah dan UPP pemerintah daerah. Pasal 82 ayat (5) menyatakan hasil konsesi yang diperoleh OP merupakan pendapatan negara, dan selanjutnya ayat (6) menerangkan bila dalam pelaksanaannya OP harus berkoordinasi dengan pemerintah daerah. Pasal-pasal tersebut menyimpulkan bila dengan diberlakukannya UU No.17/2008 maka Pemkab Gresik bukan satu-satunya yang berwenang dalam usaha mengatur, membina, mengendalikan dan mengawasi kegiatan pelabuhan. UU No. 28/2009, Pasal 135 ayat (2) menyatakan bahwa pelabuhan dikecualikan dari obyek retribusi, yaitu pelayanan jasa yang disediakan, dimiliki dan/atau dikelola oleh pemerintah, BUMN, BUMD, swasta. Artinya bahwa Pemkab. Gresik dilarang menarik retribusi terhadap 8 DUKS yang ada di wilayahnya, sehingga sumber pendapatan PAD untuk terselenggaranya pembiayaan otonomi daerah otomatis juga berkurang. UU No. 17/2008 dan UU No. 28/2009 telah mengurangi bahkan menghilangkan kewenangan Pemkab. Gresik untuk menarik retribusi dari pelayanan kepelabuhan.

Berdasarkan Pasal 344 ayat (1) UU No.17/2008, Pemkab. Gresik masih dapat menyelenggarakan kegiatan pengusahaan di pelabuhan, jika mengacu pada Pasal 344 ayat (2) UUNo.17/2008, maka dalam waktu paling lama 3 (tiga) tahun sejak tahun 2008 yaitu tahun 2012, Pemkab. Gresik harus sudah menghentikan penarikan retribusi.Sesuai dengan Pasal 32 ayat (1), (2), dan (3) UU No. 17/2008 maka harus dibentuk Badan Usaha atau Perusahaan Angkutan Laut Nasional untuk menggantikan fungsi Pemkab. Gresik dalam hal pengelolan DUKS atau berbagai usaha jasa sesuai dengan Pasal 31 ayat (2). Bila sampai dengan sampai dengan tenggang waktu yang telah diberikan oleh Pasal 344 ayat (2) UU No.17/2008 yaitu pada tahun 2012 Pemkab. Gresik masih melakukan penarikan retribusi atas 8 DUKS yang ada di wilayahnya maka perbuatan tersebut masuk dalam kategori maladministrasi, dengan pelanggaran karakter kelompok ketiga, yaitu bentuk pelanggaran terhadap hukum dan peraturan perundang-undangan.

Penyelesaian sengketa atas perbuatan Pemkab. Gresik tersebut dapat diselesaikan dengan dua mekanisme, yaitu: pertama, melakukan pengaduan kepada Ombudsman (non litigasi) untuk menyelesaikan laporan sengketa yang terjadi melalui mediasi dan konsiliasi atas permintaan para pihak (berdasarkan Pasal 8 ayat (1) huruf e UU No. 37/2008 jo Pasal 46 
UU No. 25/2009); kedua, menyelesaikan sengketa pelayanan publik melalui pengadilan atau litigasi (berdasarkan Pasal 51, 52, dan 53 UU No.25/2009). Pengadilan yang terkait adalah Pengadilan Umum dan Pengadilan Tata Usaha Negara, sebab dimensi dalam sengketa ini adalah dimensi administratif, dimensi perdata, dan dimensi pidana.

\section{Perbedaan Karakteristik Retribusi dan Karakteristik Pajak}

Pasca diundangkannya UU No. 17/2008 dan UU No.28/2009, Pemkab. Gresik tidak begitu saja melaksanakan ketentuan pasal-pasal terkait dengan kewenangan yang mereka peroleh sebelumnya. Dasar pemikiran atas penolakan tersebut adalah pihak Pemkab. Gresik akan sangat kehilangan sumber PAD yang berasal dari retribusi. Sampai saat ini juga masih dilakukan penarikan retribusi terhadap DUKS yang ada di wilayah Gresik, jika hal itu masih dilakukan maka sesuai dengan teori kewenangan maka tidak ada keabsahan atas pelaksanaan kewenangan tersebut. Penulis berpendapat bahwa kewenangan Pemkab. Gresik untuk melaksanakan otonomi daerah, melakukan pengelolaan atas wilayah DUKS, dan menarik retribusi adalah berdasarkan teori atribusi.

Philiphus M. Hadjon merumuskan atribusi merupakan pembentukan wewenang tertentu dan pemberiannya kepada organ tertentu, dan yang dapat membentuk wewenang adalah organ yang berwenang berdasarkan peraturan perundang-undangan. ${ }^{28}$ Indroharto mengemukakan bahwa atribusi adalah pemberian wewenang pemerintah yang baru oleh suatu ketentuan dalam perundang-undangan baik yang diadakan oleh original legislator ataupun delegated legislator. ${ }^{29}$ Artinya jika Pemkab. Gresik dapat menarik retribusi terhadap DUKS di wilayahnya berdasarkan Perda No. 3/2001, Perda No. 19/2001, dan Perda No. 9/2002 serta Keputusan Bupati Gresik No.63/2002. Perda tersebut diatas adalah merupakan turunan dari peroleh wewenang secara atribusi, yaitu dari Pasal 18 ayat (5) dan (6), pasal 18A ayat (2) UUD NRI 1945. Pada tataran legislasi, kewenangan Pemkab. Gresik berasal dari UU No. 21/1992 (UU Pelayaran), UU No. 22/1999 (UU Pemerantahan daerah), UU No. 25/1999 (UU Perimbangan Keuangan antara Pemerintah Pusat dan Daerah), dan UU No. 34/2000 (UU Pajak Daerah dan Retribusi Daerah).

Sumber kewenangan atribusi yang dimiliki Pemkab. Gresik yaitu UU No. 21/1999 dirubah oleh UU No.17/2008 dan UU 34/2000 dirubah dengan UU No.28/2009, maka secara otomatis pemberlakuan Perda No. 3/2001, Perda No. 19/2001, dan Perda No. 9/2002 serta Keputusan Bupati Gresik No. 63/2002 adalah tidak sah. Artinya pasal-pasal yang dianut Perda tersebut di atas bertentangan antara Undang-Undang yang baru, maka Perda lama tersebut dapat dinyatakan cacat hukum dan termasuk dalam kategori batal demi hukum. Suatu wewenangan diperoleh tanpa dasar hukum maka perbuatan hukum pihak tersebut

\footnotetext{
28 Philiphus M. Hadjon, “Tentang Wewenang”, Yuridika, No. 5 \& 6 Tahun XII, Sep - Des 1997, h. 2.

29 Lukman Hakim,Filosofi Kewenangan Organ \& Lembaga Daerah - Perspektif Teori Otonomi \& Desentralisasi dalam Penyelenggaraan Pemerintahan Negara Hukum dan Kesatuan, Malang: Setara Press, Malang, h. 126.
} 
adalah batal demi hukum. Secara teoritis termasuk didalamnya cacat prosedur dan cacat substansi. Tenggang waktu yang diberikan oleh UU No. 17/2008 hanya 3 tahun untuk masa peralihan kewenanan, itu berarti hanya sampai tahun 2011 Pemkab. Gresik dapat menarik retribusi atas DUKS di wilayahnya. Penarikan retribusi sejak mulai tahun 2011 sampai dengan 2013 adalah perbuatan yang dikategorikan sebagai batal demi hukum.

Terdapat wacana untuk menggantikan mekanisme penarikan retribusi (dalam rangka memperoleh PAD) dengan mekanisme penarikan pajak. Penulis berpendapat hal tersebut adalah tidak tepat, karena definisi dan hakekat dari retribusi dan pajak adalah sesuatu yang berbeda. Definisi pajak menurut Soeparman Soemahamidjaja, "Pajak adalah iuran wajib berupa uang atau barang, yang dipungut oleh penguasa berdasarkan norma-norma hukum, guna menutup biaya produksi barang-barang dan jasa-jasa kolektif dalam mencapai kesejahteraan umum". ${ }^{30}$ Wacana penggantian "penarikan retribusi" dengan "penarikan pajak" adalah kurang tepat, karena karakter keduanya adalah berbeda. Persamaan sumber peroleh PAD, tidak secara otomatis dapat secara langsung menukar penerapannya terhadap pengelolan jasa kepelabuhan atas 8 DUKS yang ada di wlayah Gresik.

Perbedaan antara retribusi dan pajak menurut Josef Riwu Kaho, adalah: 1) Pajak daerah adalah lapangan yang belum diusahakan oleh pemerintah atasannya (Pemerintah Pusat atau Pemerintah Kabupaten/Kotamadya), lapangan pajak yang sama, tidak boleh dipungut oleh dua atau lebih instansi/pihak. Pajak yang kembar tidak diperbolehkan dalam hukum pajak tetapi diperbolehkan dalam retribusi; 2) Pajak daerah dipungut tanpa mempersoalkan ada atau tidak adanya pemberian jasa oleh daerah, sedangkan pungutan retribusi didasarkan pada pemberian jasa kepada pemakai jasa; 3) Pajak daerah dibayar oleh orang-orang tertentu, yaitu para wajib pajak, tetapi retribusi dibayar oleh siapa saja yang telah mengenyam jasa dari pemerintah daerah, baik anak-anak, oang dewasa, dan sebagainya; 4) Umumnya pajak dikenakan setahun sekali, pembayaran dapat dilakukan sekaligus atau dicicil. Retribusi dapat pula dilakukan berulang kali terhadap seseorang, sepanjang ia berulang kali pula menikmati jasa yang disediakan. Retribusi pembayarannya jarang diangsur sebab jumlah penarikannya relatif kecil. Kelebihan-kelebihan seperti di ataslah yang memberikan keleluasaan kepada pemerintah daerah dalam mengusahakan sektor ini (retribusi) dan karenanya, sedikit lebih baik dibandingkan dengan pajak. ${ }^{31}$ Oleh sebab itu sangatlah tidak tepat untuk mengantikan mekanisme penarikan retribusi dengan penarikan pajak kepada DUKS di wilayah Kabupaten Gresik.

\section{Pihak-Pihak Yang Diuntungkan dan Dirugikan Dalam Penarikan Retribusi Oleh Pemerintah Kabupaten Gresik}

Dalam permasalahan ini terdapat tiga pihak yang secara langsung saling berkaitan,

\footnotetext{
30 Wirawan B. Ilyas \& Richard Burton, Hukum Pajak, Jakarta: Salemba Empat, 2010, h. 6.

31 Adrian Sutedi, Op.Cit, h. 143.
} 
yaitu Pemkab. Gresik, PT. Pelindo III (Persero) dan 8 DUKS (obyek retribusi). Berdasarkan uraian dalam bab-bab sebelumnya maka penulis menyatakan pihak yang mendapat keuntungan dan kerugian dapat dianalisis dari masa pemberlakuan otonomi daerah dan selanjutnya setelah diundangkannya UU No. 17/2008 dan UU No. 28/2009 (setelah tahun 2011). Sesudah pelaksanaan otonomi daerah (berdasarkan UU 22/1999-sesudah tahun 2000) Pihak PT. Pelindo pasti merasa dirugikan dengan pemberlakuan otonomi daerah, sebab jika sebelumnya pihak PT. Pelindo III (Persero) adalah pihak yang berwenang penuh atas pengelolaan 8 DUKS, maka setelah perberlakuan otonomi kewenangannya diambil alih oleh Pemkab. Gresik.

Status PT. Pelindo III (Persero) bukan lagi sebagai "regulator" melainkan hanya sebagai "operator" pelabuhan, hal ini secara otomatis mengubah bisnis PT. Pelindo III (Persero) dari "Port Operator" menjadi “Terminal Operator". Hal tersebut tentu saja juga akan menghilangkan status PT. Pelindo III (Persero) sebagai BUMN yang dapat memberikan pemasukan bagi Pemerintah Pusat. Pemkab. Gresik dalam hal ini adalah pihak yang sangat diuntungkan, karena mendapat tambahan PAD. Pada tahun 2005, menurut Kasi Kepelabuhan Gresik, dalam setahun pendapatan dari jasa labuh maupun tunda sekitar Rp. 13-14 miliar. Dari jumlah itu, pendapatan bersih diperoleh Pemkab. Gresik sebesar Rp. 3-4 miliar, jumlah yang sangat jauh jika dibandingkan dengan perolehan sektor pajak parkir yang hanya mencapai Rp. 140 juta per tahun.

Pembentukan UU No.17/2008 dan UU No. 28/2009 (setelah tahun 2011) secara langsung mengakibatkan kerugian pada Pemkab. Gresik, sebab selama beberapa tahun telah memperoleh hasil yang besar bagi PAD dari sektor retribusi kepelabuhan. Pemberian jangka waktu tiga tahun yang diberikan oleh UU No.17/2008 setidaknya telah memberikan waktu kepada Pemkab untuk dapat mempersiapkan diri mulai "kehilangan lagi" sumber PADnya dari sektor retribusi. Setidaknya Pemkab. Gresik dapat mencari cara lain sebagai upaya mengganti sektor tersebut, tetapi dengan cara yang sesuai dengan hukum. Jika setelah lewat waktu 3 tahun, dari masa transisi (yaitu tahun 2009 s/d 2011), Pemkab. Gresik masih melakukan penarikan retribusi terhadap 8 DUKS yang ada di wilayahnya, maka pihak yang dirugikan tentu saja warga negara Indonesia yang dalam hal ini adalah para pihak DUKS tersebut.

\section{Kesimpulan}

Setelah diundangkan UU No.17/2008 dan UU No. 28/2009 maka Pemkab. Gresik masih diberikan tenggang waktu 3 (tiga) tahun yaitu sampai tahun 2012 untuk mengalihkan penarikan retribusi terhadap mekanisme yang lainnya dalam rangka memperoleh PAD. Tahun 2013, Pemkab. Gresik sudah tidak berwenang lagi untuk menarik retribusi terhadap 8 DUKS yang ada di wilayahnya. Pihak yang dirugikan saat ini (tahun 2013) dengan masih tetap diberlakukannya penarikan retribusi terhadap 8 DUKS adalah pihak DUKS dan 
Pemerintah Pusat. UU No.17/2008 kembali memberikan kesempatan kepada BUMN atau BUMD untuk melakukan pengelolaan terhadap wilayah kepelabuhan, sehingga otomatis menghilangkan monopoli Pemkab. Gresik sebelumnya.Wacana mengganti penarikan retribusi menjadi penarikan pajak adalah tidak tepat karena berbagai perbedaan karakter dan hakekat antara keduanya.

Pelaksanaan otonomi daerah harus tetap memperhatikan beberapa hal yaitu: pertama, seharusnya tidak membuat Pemerintah Daerah (khususnya Pemkab. Gresik) dapat melakukan monopoli terhadap suatu obyek retribusi untuk PAD, AAUPB tetap harus diperhatikan ketika menarikretribusi; kedua, tetap memperhatikan konteks Negara Kesatuan Republik Indonesia dan Pasal 18 UUD NRI 1945 (Bab Pemerintah Daerah); ketiga, otonomi daerah seharusnya tidak merugikan berbagai pihak (Pemerintah Pusat dan/atau warga negara) dan hanya memberikan keuntunganbagi satu pihak (Pemerintah Daerah/Pemkab. Gresik). Pembentukan peraturan perundang-undangan harus memperhatikan hirarki peraturan di atasnya dan masing-masing pihak harus berlaku sesuai dengan hukum positif yang berlaku, sehingga wewenang yang dilakukan tidak menjadi batal demi hukum. Penyalahgunaan wewenang, kesalahan prosedur dan materi hendaknya dapat diselesaikan sesuai dengan mekanisme hukum yang telah ditetapkan.

\section{DaftarBacaan}

\section{Buku}

B. Ilyas, Wirawan \& Richard Burton, Hukum Pajak, Jakarta: Salemba Empat, 2010.

Fauzan, Muhammad, Hukum Pemerintahan Daerah - Kajian Tentang Hubungan Keuangan antara Pusat dan Daerah, Yogyakarta: UII Press, 2006.

Hakim, Lukman, Filosofi Kewenangan Organ \& Lembaga Daerah - Perspektif Teori Otonomi \& Desentralisasi dalam Penyelenggaraan Pemerintahan Negara Hukum dan Kesatuan, Malang: Setara Press, 2001.

Istanto, F. Sugeng, Beberapa Segi Hubungan Pemerintah Pusat dan Daerah dalam Negara Kesatuan Indonesia, Yogyakarta: Karyaputera, 1971.

Kurniawan, Agung, Transformasi Pelayanan Publik, Yogyakarta, Pembaruan, 2005.

Mahmudi, Manajemen Keuangan Daerah, Jakarta: Erlangga, 2010.

Mahmud Marzuki, Peter, Penelitian Hukum, Jakarta: Kencana, 2009.

Saleh, Syarif, Otonomi dan Daerah Otonom, Jakarta: Endang, 1953.

Sutedi, Adrian, Hukum Pajak dan Retribusi Daerah, Bogor: Ghalia Indonesia, 2008.

--------, Implikasi Hukum Atas Sumber Pembiayaan Daerah Dalam Kerangka Otonomi Daerah, Jakarta: Sinar Grafika, 2009. 
Subarsono, AG., Pelayanan Publik yang Efisien, Responsif, dan Non-Partisan-Mewujudkan Good Governance Melalui Pelayanan Publik, Yogyakarta: Gadjah Mada University Press, 2008.

Sirajudin, Didik S., Winardi, Hukum Pelayanan Publik Berbasis Partisipasi \& Keterbukaan Informasi, Malang: Setara Press, 2011.

Toet Hendratno, Edie, Negara Kesatuan, Desentralisasi, dan Federalisme, Yogyakarta: Graha Ilmu, 2009.

Wayong, J., Asas dan Tujuan Pemerintahan Daerah, Jakarta: Jambatan, 1975.

Widjaja, H.A.W. Percontohan Otonomi Daerah di Indonesia, Jakarta: Rineka Cipta, 1998.

\section{Makalah}

Elan, Umi, "Pengaruh Keputusan Kerja Trhadap Kinerja Karyawan PT. Pelindo III Cabang Gresik" Cahaya Kampus, Jurnal Ilmiah Universitas Gresik, Vol. 14 No. 1, Mei-Oktober 2013.

M. Hadjon, Philipus, "Tentang Wewenang”, Yuridika, No. 5 \& 6 Tahun XII, September Desember, 1997. 